\title{
LEADERSHIP STYLE AND ITS IMPACT ON EMPLOYEE MOTIVATION IN IT / ITES SECTOR
}

\author{
DR. C B. RAGOTHAMAN
}

Professor, Department of Management Studies, Rajalakshmi Engineering College, Thandalam, Chennai, India

\begin{abstract}
Leaders are the torch bearers. Leadership is the art of empowering and mobilizing others to want to accomplish a mutually agreed-upon goal while advancing the group's integrity and morale. Leaders help to achieve the vision, mission and goals of the Organisation. Strong leadership in adverse times helps to win the trust of the stakeholders. These leaders develop followers by creating a direction for them to follow, yet giving them the freedom to control their own behavior. Leaders should be charismatic, visionary, inspirational, and intellectually stimulating. Leaders decide the fate of the Organisation. Leadership is the product of an individual's approach to the job of leading and any leader can alter their approach and have a fresh impact on those leads.

KEYWORDS: Motivation, Leadership Styles, Performance
\end{abstract}

Received: Jun 06, 2020; Accepted: Jun 26, 2020; Published: Aug 07, 2020; Paper Id.: IJMPERDJUN2020675

\section{INTRODUCTION}

The success of an organization is the result of combination of factors like financial, material and technological resources, logistics, and human capital. These factors are put together to achieve the desired goals consistent with the corporate mission. In this context, firms are in constant seeking of the best individuals who will lead and carry out this journey to success. These individuals are expected to have special characteristics that ensure that their actions will turn out into positive results for the organization. These extraordinary individuals are the leaders. Leaders decide the activities to be carried out and direct others to pursue their work. In the process of leading and influencing others to do their work a leaders adopts variety of methods. Some of the leaders are task oriented and few others concentrate on nurturing relationship and individuals at work. Studies show that leaders are sometimes transactional only, at times transformational. Transaction oriented people often are workaholic and tend to get the work done but forget human relations. We are living in an arena, where people at work consider their work environment to be filled with positivity, expect a leader to be supportive and educate and empower the team members for higher order performance. Traditional leadership theories classify leaders as autocratic, democratic and laissez-faire. Today with the change the workforce and work, more importance is given to human resources. In order to bring the best from the people at work, the leader play a vital role. He must foster creativity to solve the challenges and perform efficient work. Therefore keeping these workplace variables, the present study is conducted to find out the leadership styles that are predominantly practiced in IT / ITES companies and its impact on Employee Motivation. Motivation at work helps them to perform better and bring out the best in them. The changing workplace requires a change in the leadership style, friendlier collaborative workplace that inspires workers to perform better. Keeping the importance of leadership and motivation, the present study aims to identify the leadership styles that are practiced in IT / ITES companies, Motivations of present day workforce and the 
impact of different leadership on employee motivation.

\section{Need \& Importance of the Study}

The Fred Fiedler presents the theory of Fiedler leadership contingency model theory in which he proposed that effective employees performance depended upon the proper match between a leaders' ability to lead is contingent upon situational factors that include the leaders' capabilities, preferred style, and behavior, competency of employees. This theory propounded that leaders should adopt that style which best to the situation and immediately stimulate the employee performance. Leadership is increasingly understood to involve persuasion and explanation as well as ability to identify, affirm, and renew the values of the group the leader represents. Managerial expertise, technical skills, cultural literacy and other relevant knowledge and skills are not sufficient virtues for the leaders whose lives will be dedicated to public services. An effective leader has a responsibility to provide guidance and share the knowledge to the employee to lead them for better performance and make them expert for maintaining the quality. This also helps the management in succession planning and offers team members great responsibility. The introduction of the clear standards of leadership promotes the core values and maturity on their role and responsibility.

\section{Review of Literature}

Leadership is an important function of an organisation which has an impact on the various aspects of the organization. Effectiveness of Leadership style can be accessed through variables such as

- Having high Performing Team

- Highly Motivated workforce

- Employees with good levels of Job satisfaction

- Innovative and creative team

BabakNemaei (2012) $)^{1}$ affirmed that participative style of leadership is the most effective. Transformational leadership has a negative effect on motivation, job satisfaction. The research confirmed that efficient use of participative leadership style produces better outcomes compared to the use of transformational leadership style.

Burhanuddin $(2013)^{2}$ in his research found that Participative Management has a positive effect on employee performance behavior.

- At the micro level it indicates Employee Performance but at the macro level it indicates Organisational Climate.

- Employee performance behaviour can be enhanced by promoting individual capability and relations in their work place behavior.

Also, H. M. Thamrin( 2012) $)^{3}$ affirmed that Transformational leadership has a significant positive relationship on organizational commitment and employee performance. Transformational leadership can raise organizational commitment

\footnotetext{
${ }^{1}$ Babak Nemaei(2012), The Impact of participative leadership on employee's motivation, job satisfaction and innovation,The British University in Dubai.

${ }^{2}$ Burhanuddin (2013), Participative Management and its Relationships with Employee Performance Behavior: A Study in the University sector in Malang Indonesia. University of Adelaide

${ }^{3}$ H. M. Thamrin (2012), The Influence of Transformational Leadership and Organizational Commitment on Job Satisfaction and Employee Performance, International Journal of Innovation, Management and Technology, Vol. 3, No. 5, October.
} 
and employees' performance and Job satisfaction is affected by organizational commitment which can improve employee performance.

Batool, B. F. $(2013)^{4}$ confirmed the effect of

- Individual consideration - It had a positive impact on the employee performance leading to strong organisational commitment.

- Inspirational motivation -exerts negative but insignificant effect on performance.

Every organisation desire employees that go beyond their daily routine work and take steps to improve their individual productivity. As an organisation investing in innovation and recognition increases the employee productivity. Promotion, recognition and perks have a direct impact on the working of employees. A positive increase in pay praises, bonus, environmental perks, and benefit practices motivate them go beyond their daily task and perform great at work.

A motivated workforce helps the organisation to achieve the goals, thereby identification of motivation factors is an important task. Seyed Abdol Rasoul Hosseini (2014) ${ }^{5}$ explored the motivation factors like - social needs, job interest, self-efficiency satisfaction, communication skills, job promotion, power, physiological needs, wages, and the job itself. It was affirmed that

- Social needs have the strongest factor in predicting job motivation. Employees show different reactions to different rewards

- Higher the position, higher the job satisfaction.

Alghazo, A. M., \& Al-Anazi, M. (2016) ${ }^{6}$ in their study summarised that

- Leaders who adapt participative and transformational leadership are more likely to motivate their employees.

- There is a positive correlation between transformational style and employee motivation.

- There is negative correlation between transactional style and employee performance.

Supaman, L., Nasir, M., \& Serif, S. (2019) ${ }^{7}$. States that leadership is a character, habit, and personality that distinguish a person in interacting with others. The analysis showed that the leadership style had a significant effect on job motivation and LPD performance. Job motivation has a significant effect on LPD performance. While the indirect influence of leadership style on LPD performance shows the important role of job motivation in improving LPD performance.

\section{OBJECTIVES OF THE STUDY}

- To identify the Leadership Styles practiced in IT / ITES companies in Chennai

\footnotetext{
${ }^{4}$ Batool, B. F. (2013). An empirical study on effect of transformational leadership on organizational commitment in the banking sector of Pakistan. IOSR Journal of Business and Management, 8(2), 38-44.

${ }^{5}$ Hosseini, S. A. R. (2014). Components of organizational culture based on Denison model. Kuwait Chapter of Arabian Journal of Business and Management Review, 33(2572), 1-12.

${ }^{6}$ Alghazo, A. M., \& Al-Anazi, M. (2016). The Impact of Leadership Style on Employee's Motivation. International Journal of Economics and Business Administration, 2(5), 37-44.

${ }^{7}$ Supaman, L., Nasir, M., \& Serif, S. (2019). The Effect of Leadership on Working Conditions, Work Motivation, and Organization Commitment. Global Journal of Management And Business Research.
} 
- To measure the motivation for work of the employees working in IT/ITES companies in Chennai

- To Evaluate the impact of Leadership Style on Employee Motivation

\section{SAMPLING DETAILS}

- Data for the Study: Primary Data for the study is collected from men and women working in various IT/ ITES Companies in Chennai.

- Sample Size: 150

- Sampling Method \& Data Collection Instrument: Convenience sampling method is used for data collection. Primary Data is collected through a structured questionnaire.

- Statistical Tools Used: Percentage Analysis, Factor Analysis and Regression are applied in the study.

Table 1: Respondents Profile

\begin{tabular}{|c|c|c|c|}
\hline Variable & Classification & No. of respondents & Percentage \\
\hline \multirow{3}{*}{ Age } & $21-30$ & 93 & 62 \\
\cline { 2 - 4 } & $31-40$ & 42 & 28 \\
\cline { 2 - 4 } & $41-50$ & 9 & 6 \\
\cline { 2 - 4 } & $50 \&$ above & 6 & 4 \\
\hline \multirow{2}{*}{ Gender } & Female & 65 & 43 \\
\cline { 2 - 4 } & Male & 85 & 57 \\
\hline \multirow{3}{*}{ Level } & Junior & 29 & 50 \\
\cline { 2 - 4 } & Middle & 75 & 31 \\
\cline { 2 - 4 } & Senior & 46 & \\
\hline
\end{tabular}

Source: Primary Data

The above table describes the respondent's profile. For the present study details relating to Age, Gender and the current level in their organisation were collected. $62 \%$ of the respondents belong to the age group of 21-30 years while the $28 \%$ belong to the age group of 31-40. A majority of 57\% respondents are Male. It was also found that a majority of $50 \%$ of the respondents hold the Top Level Positions while the $31 \%$ of them are in Middle Level Positions.

\section{Data Analysis}

The Study applied Factor analysis to measure the Factors Measuring the type of leadership practiced and the Factors Measuring motivation in the Workplace in various IT/ITES companies. The Analysis summary is presented below

\section{FACTORS DETERMINING LEADERSHIP STYLE}

In order to measure the leadership style 20 variables measuring various leadership practices are used in the study. Factor analysis a data reduction tool enabled the researcher to reduce these 20 variables into three factors measuring leadership style.

KMO and Bartlett's Test of Sphericity is applied as a initial test to find out the sample size is adequate to proceed with factor analysis. 
Table 2: KMO and Bartlett's Test on Factors Measuring Leadership

\begin{tabular}{|c|c|c|}
\hline \multicolumn{2}{|c|}{ Kaiser-Meyer-Olkin Measure of Sampling Adequacy } & $\mathbf{. 9 3 5}$ \\
\hline Bartlett's Test of Sphericity & Approx. Chi-Square & 1956.787 \\
\hline & Df & 190 \\
\hline & Sig. & .000 \\
\hline
\end{tabular}

Source: Computed Data

From the above table, it is found that the KMO measure of sampling adequacy along with Bartlett's test of sphericity, with approximate chi-square value of 1956.787 and it is statistically significant at 5\% level. Therefore it is clear that the sample size is adequate to proceed with further analysis.

The study applying Rotated Factor analysis, considered variables with more than 0.5 eigen value only, to ensure data validity. The Rotated Component Matrix along with eigen value of each statement measuring the leadership style and the Name given in the study for further analysis are presented below.

Table 3: Rotated Component Matrix- Factors Measuring Leadership Style

\begin{tabular}{|c|c|c|c|}
\hline Factor No. & Leadership Variables & e-values & Name given to the Factor \\
\hline \multirow[t]{11}{*}{ 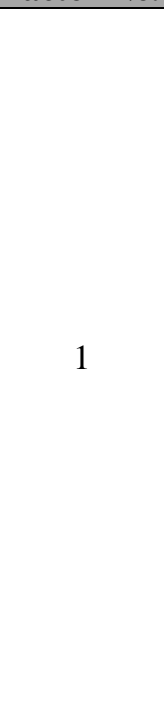 } & Goal Setting \& Recognition of other 's Performance & .664 & \multirow{11}{*}{$\begin{array}{l}\text { Transformational } \\
\text { Leaders }\end{array}$} \\
\hline & Very attentive to people's needs and concerns & .598 & \\
\hline & $\begin{array}{l}\text { Encourages Team members to question their most } \\
\text { way of thinking \& doing }\end{array}$ & .710 & \\
\hline & $\begin{array}{l}\text { Goes out of the way to make others feel good around } \\
\text { him }\end{array}$ & .631 & \\
\hline & Provides challenges to help grow & .637 & \\
\hline & $\begin{array}{l}\text { Ensures everyone in the team participates in the } \\
\text { decision making process }\end{array}$ & .706 & \\
\hline & Invites Feedback and works with a team on solutions & .718 & \\
\hline & $\begin{array}{l}\text { Consults \& communicates with the whole team } \\
\text { regularly }\end{array}$ & .746 & \\
\hline & $\begin{array}{l}\text { Agrees targets and objectives with the individuals } \\
\text { and expects a degree of self-inspection }\end{array}$ & .695 & \\
\hline & Guides individuals on how to perform & .672 & \\
\hline & $\begin{array}{l}\text { Agrees expectations with the team and deals with } \\
\text { them when they are not met }\end{array}$ & .732 & \\
\hline \multirow{5}{*}{2} & $\begin{array}{l}\text { Listens to others and coaches them to bring out their } \\
\text { best }\end{array}$ & .838 & \multirow{5}{*}{ Participative Leaders } \\
\hline & Asks others for their thoughts and perspectives & .783 & \\
\hline & $\begin{array}{l}\text { Genuinely positive, enthusiastic and cast a } \\
\text { compelling vision }\end{array}$ & .767 & \\
\hline & $\begin{array}{l}\text { Often talks about shared mission, vision and values } \\
\text { with the team }\end{array}$ & .590 & \\
\hline & Simple presence can inspire others confidence & .567 & \\
\hline \multirow{4}{*}{3} & Often avoids getting involved and tends to be passive & .665 & \multirow{4}{*}{$\begin{array}{l}\text { Transactional } \\
\text { Leaders }\end{array}$} \\
\hline & Loosely monitors and steps only if things go bad & .728 & \\
\hline & $\begin{array}{l}\text { The power to influence others comes primarily from } \\
\text { his/her status position }\end{array}$ & 639 & \\
\hline & $\begin{array}{l}\text { Even though a task can be easily performed by } \\
\text { himself, he/she delegates it }\end{array}$ & .711 & \\
\hline
\end{tabular}

Extraction Method: Principal Component Analysis. Rotation Method: Varimax with Kaiser Normalization. A Rotation converged in 7 iterations. 
The above grouping enables to reduce data. The 20 statements were applied to measure different style of leadership practiced in IT/ITES companies and grouped into 3 three types of leadership styles. The leadership styles that have been named in the study based on the variables are Participative, Transformational and Transactional Leadership style.

- Transformational Leaders: In the present study a set of respondents have stated that their leaders poses transformational leadership qualities. A Transformational Leader is a person who sets goals for his team, recognises the performance of each and every member, be a people friendly person, always available to encourage them with positive words, offer challenging jobs to equip, provides opportunity to participate in the decision making process, invites constructive feedback and agrees to the expectations of the team and willing to accept failures. A Transformational Leader helps his team to transform their skills and abilities from one level to another. He is not work oriented alone work with people oriented. He is more of Listening and Speaking type of a leader.

- Participative Leaders : In the IT/ITES sector the respondents believes that this group of leaders listen and coach the team members to bring their best, collects inputs from team members periodically, he is also genuinely positive and enthusiastic but, finally have compelling vision. He believes that his presence will inspire the team members and often talks about shared mission and values with the team. He is more of Consult, Coach and Communicate type of leader.

- Transactional Leaders: This category of leaders often tends to avoid getting involved and remain passive. They tend to be reserved and non participative, steps in only when things go wrong. The power to influence others comes primarily from his/her status position. Even though a task can be easily performed by himself, he/she delegates it. He demonstrates more of boss is always right.

\section{FACTORS MEASURING EMPLOYEE MOTIVATION AT WORK}

The drive for taking up an employment varies from variety of means. Starting from Maslow's theory Money, Safe \& Secured job, Recognition, Good Work Environment and so many other factors... in the present study we are concentrating on the variables that IT/ITES employees are getting motivated. In the present study 10 statements were administered to measure the respondent's perception. Factor analysis a data reduction technique is applied to reduce these 10 variables into factors measuring the employee motivation in the IT/ITES companies. KMO Bartlett's test is conducted to proceed with further analysis.

Table 4: KMO and Bartlett's Test on Factors Measuring Employee Motivation

\begin{tabular}{|c|c|c|}
\hline \multicolumn{2}{|c|}{ Kaiser-Meyer-Olkin Measure of Sampling Adequacy } & $\mathbf{. 9 2 2}$ \\
\hline Bartlett's Test of Sphericity & Approx. Chi-Square & 978.380 \\
\hline Df & 45 \\
\hline Sig. & .000 \\
\hline
\end{tabular}

Source: Computed Data

The above table shows that KMO and Bartlett's test of Sphericity is with Chi square value of 978.380 is statistically significant at $5 \%$ level. This enables the researcher to proceed with further analysis. The study considered statements with eigen value more than 0.5 only to ensure data validity. The Following table is a summary of the Rotated Component Matrix on the factors measuring Employee Motivation. 
Table 5: Rotated Component Matrix- Factors Measuring Employee Motivation

\begin{tabular}{|c|c|c|c|}
\hline Factor No. & Motivation Variables & e-values & Name given to the Factor \\
\hline \multirow[t]{2}{*}{1} & $\begin{array}{l}\text { Punctuality \& Regularity and being Disciplined at } \\
\text { work }\end{array}$ & .643 & \multirow{2}{*}{$\begin{array}{l}\text { Job Oriented Factors at } \\
\text { Work }\end{array}$} \\
\hline & I am driven by challenging task & .894 & \\
\hline \multirow{3}{*}{2} & Content with my work & .792 & \multirow{3}{*}{$\begin{array}{l}\text { Enrichment Oriented } \\
\text { Factors at Work }\end{array}$} \\
\hline & $\begin{array}{l}\text { Tasks help me to strengthen my skills and also adds } \\
\text { to my personal growth }\end{array}$ & .508 & \\
\hline & $\begin{array}{l}\text { I am willing to take up extra and high level tasks for } \\
\text { the organisation }\end{array}$ & .728 & \\
\hline \multirow{5}{*}{3} & I assess my growth and downfalls on a regular basis. & .791 & \multirow{5}{*}{$\begin{array}{l}\text { Self-Driven Factors at } \\
\text { Work }\end{array}$} \\
\hline & I have learnt news skills along with my work & .702 & \\
\hline & I have set my future goals and aspire to achieve them. & .821 & \\
\hline & $\begin{array}{l}\text { I am constantly assessing myself after every task in } \\
\text { order to improve my performance }\end{array}$ & .687 & \\
\hline & $\begin{array}{l}\text { I take feedbacks from my immediate superiors on a } \\
\text { regular basis }\end{array}$ & 639 & \\
\hline
\end{tabular}

Extraction Method: Principal Component Analysis. Rotation Method: Varimax with Kaiser Normalization. A Rotation converged in 8 iterations.

The above grouping enables to reduce data. The 10 statements measuring the factors that influence the motivational levels now been grouped into 5 factors and named and describe below.

- Job Oriented Factors at Work: Challenging work helps develop interests of the employee and thereby motivates the employee to do better and helps them develop themselves. Challenging work might have a negative impact also on the employees. If the guidance and the resources are insufficient, it might frustrate the employee and cause dissatisfaction. Punctuality, being regular and disciplined at work are the factors that inspire them a lot. A job that involves these variables motivates them to join IT/ITES companies.

- Enrichment Oriented Factors at Work: Prospects in job and if the task allotted helps the employee to grow personally, the opportunities in the job motivate the employee. It pushes the employee to make the best out of the job and grow individually. These employees are also content with their job. They also feel that a job that offers platform to strengthen their skill set and enables personal growth motivates them.

- Self-driven Ractors at Work: Employees who are self-driven are so passionate that they make sure they indulge themselves in a series of self-assessment procedures. They also believe in the idea of feedback. They constantly assess their performance.

\section{INFLUENCE OF LEADERSHIP STYLE ON MOTIVATION}

The Study measures the influence of Different Type of Leadership Style on Employee Motivation. Linear Regression is used to measure the influence of Leadership Style.

The following table presents the summary of analysis.

Table 6: Influence of Transformational Leadership on Employee Motivation

\begin{tabular}{|c|l|c|c|c|c|}
\hline \multicolumn{2}{|c|}{ Transformational Leadership Style } & Sig. & R & R-Square & Adjusted R $^{2}$ \\
\hline \multirow{3}{*}{ Motivation } & Job oriented Factors & .001 & .264 & .070 & .063 \\
\cline { 2 - 6 } & Enrichment Oriented Factors & .000 & .359 & .129 & .123 \\
\cline { 2 - 6 } & Self- Driven Factors at work & .066 & .151 & .023 & .016 \\
\hline
\end{tabular}

Source: Computed Data 
The analysis shows that Transformational Leadership Style has an impact on job oriented factors and Enrichment oriented factors influencing the Employee Motivation.

Table 7: Influence of Participative Leadership on Employee Motivation

\begin{tabular}{|l|l|c|c|c|c|}
\hline \multicolumn{2}{|c|}{ Participative Leadership Style } & Sig. & R & R-Square & Adjusted R $^{\mathbf{2}}$ \\
\hline \multirow{4}{*}{ Motivation } & Job oriented Factors & .010 & .209 & .044 & .037 \\
\cline { 2 - 6 } & $\begin{array}{l}\text { Enrichment } \\
\text { Oriented Factors }\end{array}$ & 0.027 & .181 & .033 & .026 \\
\cline { 2 - 6 } & $\begin{array}{l}\text { Self- Driven Factors } \\
\text { at work }\end{array}$ & 0.008 & .216 & .047 & .040 \\
\hline
\end{tabular}

Source: Computed Data

The above table shows that, Participative Leadership style has an influence Job oriented factors, Enrichment Oriented Factors and Self-driven factors on Employee Motivation.

Table 8: Influence of Transactional Leadership on Employee Motivation

\begin{tabular}{|c|l|c|c|c|c|}
\hline \multicolumn{2}{|c|}{ Transactional Leadership Style } & Sig. & R & R-Square & Adjusted R \\
\hline \multirow{3}{*}{ Motivation } & Job oriented Factors & 0.004 & .236 & .056 & .049 \\
\cline { 2 - 6 } & Enrichment Oriented Factors & 0.000 & .305 & .093 & .087 \\
\cline { 2 - 6 } & Self- Driven Factors at work & 0.608 & .042 & .002 & -.005 \\
\hline
\end{tabular}

Source: Computed Data

The above table shows that Transactional Leadership style has an influence on Job Oriented and Enrichment Oriented Factors on Employee Motivation.

\section{CONCLUSIONS}

India's IT industry amounts to 12.3 per cent of the global market, largely due to exports. Export of IT services accounted for 56.12 per cent of total IT exports (including hardware) from India. The Business Process Management (BPM) segment accounted for 23.46 per cent of total IT exports. This sector is growing due to Rapid industrialization and growth of IT parks in the country, Partial privatization of telecommunication, Development of SEZ, A large number of resource readily available in the country and Low operating costs. This is a sector that employs good number of educated and knowledge oriented employees. In order to motivate them, direct and retain them we need good quality leaders. Many studies shows that immediate supervisor plays a major role in the career shaping inspiring potential employees for higher order jobs. The study considered three types of leadership that prevail in the IT / ITES sector, such as Transactional, Participative and Transformational Leadership. The present study analyses the factors that motivate employees to take up career in IT / ITES shows that they take up employment based on Job oriented Factors, Enrichment Oriented Factors and by Self-driven Factors. Regression is used in the study to measure the level of influence of leadership styles on the employee motivation. It is found that Transformational Leadership Style has an influence on the employees whose motivation for taking up IT/ITES career are Job Oriented and Enrichment oriented factors that are present in the industry. Participative Leadership style influence all the three factors measuring employee motivation and a transactional leadership style influence job oriented and enrichment oriented factor at work. Therefore the study shows that participative style of leaders play a vital role inspiring an IT / ITES employee to be self driven. Otherwise all the three types of leadership styles have an impact on the employee motivation on Job and Enrichment oriented factors prevailing in the industry. 


\section{REFERENCES}

1. Bass S. M, Leadership and Performance beyond Expectations, New York: Free Press, 1985.

2. Kotter, J. (1996). Leading change. Boston, MA: Harvard Business School Press.

3. Kanungo R. N, "Ethical values of transactional and transformational leaders," Canadian Journal of Administrative Sciences, Vol. 18, pp.257-265, 2001

4. George, Jithin Mathew, and Dave Hinkes. "The Best Leadership Style for Self-Managed Teams." 2016): 16 (2016). International Journal of Business and General Management (IJBGM) 5.3, Apr - May 2016; 1-6

5. Reena, "The impact of reward and recognition probrams on employee's motivation and satisfaction: An emprical study," International Review of Business Research Papers, Vol. 5, No. 4, pp.270-279, 2009.

6. Sheldene K.S., Juian B, and Nick T, "Transformational leadership and leader moral orientation: contrasting an ethic of justice and an ethic of care," Journal of the Leadership Quarterly, Vol. 21, pp.179-188, 2010.

7. Gopal, R., and Rima Ghose Chowdhury. "An Exploration of Impact of Leadership Styles and Employee Commitment." International Journal of Human Resource Management 3.2 (2014).

8. Chinyere, Ndukwe, Ikechukwu Ogeze Ukeje, and Johnpaul Chukwujindu Onele. "Leadership Styles and the Politics of Institutional Management of State-Owned Universities in Nigeria: Empirical Evidence from EBSU, South-Eastern GeoPolitical Zone, Nigeria." (2016). International Journal of Humanities and Social Sciences (IJHSS) 4. 6, Oct - Nov 2015, 91 102

9. Dimitrios, Belias. "Organizational Culture and Job Satisfaction, In Banking Sector-A Review". International Journal of Human Resources Management 3.2 (2014): 1-20. 

